\title{
First European Neogene record of true pheasants from Gorna Sushitsa (SW Bulgaria)
}

\author{
Zlatozar Boev
}

National Museum of Natural History, Bulgarian Academy of Sciences, 1 Tsar Osvoboditel Blvd, 1000 Sofia, Bulgaria, boev@nmnhs.com, zlatozarboev@gmail.com

http://zoobank.org/E9DAE47B-3FD3-48B3-82A3-66424477E3F1

\begin{abstract}
A late Miocene (Middle Turolian) ulna is described as a holotype of Phasianus bulgaricus sp. n.. This find is the
\end{abstract} first record of Neogene true pheasants in Europe.

Keywords: Gorna Sushitsa locality, Miocene avifauna, Neogene birds, pheasants, Sandanski Basin, Turolian

\section{Introduction}

- Fossil records of large phasianids

Olson (1985) summarises that Phasianinae Horsfield, 1821 were abundant in the Tertiary of Europe and all of the pre-Pliocene species have been assigned to extinct genera. The Neogene records of pheasants in Europe are extremely scant (Mlikovsky, 2002). Numerous records of large phasianids are known from the Pleistocene-Phasianus colchicus Linnaeus, 1758 (Europe), Ph. nicheti Bastin, 1933 (France; considered nomen nudum), Ph. yanshansis Wanpo Lianhai, 1984 (China), Phasianus sp. (several dozens of localities) (Tyrberg, 1998) and Ph. soemmerringii (Japan) and $P h$. versicolor Vieillot, 1825 (Japan) (Tyrberg, 2008). Several genera of large phasianids have been described from the Neogene of Mongolia and China (see the Comparison section). In the Eastern Palaearctic from the Late Pleistocene of Northern Vietnam, a number of large phasianids have been recently found: Gallus gallus (Linnaeus, 1758), Ph. colchicus, Lophura diardi (Bonaparte, 1856), L. nycthemera (Linnaeus, 1758), L. edwardsi (Oustalet, 1896), Lophura aff. imperialis Delacour \& Jabouille, 1924 / L.

Received: 22 April 2019 • Editor: Peter Shurulinkov edwardsi (Oustalet, 1896) var. hatinhensis, Chrysolophus amherstiae Leadbeater, 1829, Chrysolophus sp., Polyplectron bicalcaratum (Linnaeus, 1758), Polyplectron cf. germaini Elliot, 1866, Syrmaticus cf. reevesii (Gray, 1829), cf. Lophophorus sp. (Boev, in prep.). Therefore, the described specimen of Gorna Sushitsa represents the oldest known pheasant from European Neogene localities.

- Associated fauna and age of the Gorna Sushitsa locality

During the last decades, a very rich terrestrial megafauna has been uncovered in the locality: Bovidae Gray, 1821: Palaeoreas lindermayeri (Wagner, 1848), Paleotragus cf. rouenii Gaudry, 1861, Tragoportax amalthea (Roth \& Wagner, 1854), Prostrepsiceros rotundicornis (Weithofer, 1888), Pikermicerus gaudryi Kretzoi, 1941, Oioceros rothi (Wagner, 1857), Tragoportax sp., and Gazella sp.; Equidae Gray, 1821: Hipparion theobaldi (Lydekker, 1882), Cremohipparion mediterraneum (Roth \& Wagner, 1855), Hipparion matthewi Abel, 1926, and Hipparionini indet.; Rhinocerathisae: Ceratotherium neumayeri Osborn, 1900 
and Chilotherium sp.; Giraffidae Gray, 1821: Helladotherium duvernoyi Gaudry 1860 and Giraffidae gen.; Chalicotheriidae Gill, 1872: Ancylotherium pentelicum (Gaudry \& Lartet, 1856) and Chalicotherium goldfussi J. J. Kaup, 1833; Cercopithecidae Gray, 1821: Mesopithecus pentelicus Wagner, 1839; Suidae Gray, 1821: Propotamohoerus sp.; Hyaenidae Gray, 1869: ?Hyaenotherium magnum Simeonov, 1989 (now a synonym of Hyaenictitherium wongii (Zdansky, 1924)); Proboscidea indet. (Spassov et al., 2006; Spassov et al., 2019).

Spassov et al. (2019) precise that Gorna Sushitsa site represents a complex of 12 localities. The age of the site based on the collected specimen of the described pheasant is determined as Middle Turolian. This site is mentioned as GS8. Böhme et al. (2018) dated it to $7.36 \mathrm{Mya}$, i.e. ca. 30000 years older than the Pikermi locality in Greece, using a complex of methods of sedimentology, palaeontology and palaeomagnetism. The dominant landscape around the GS8 site is characterised as xerophytic open woodland/ shrubland (Spassov et al., 2019).

\section{Material and methods}

The examined find represents an incomplete left ulna bone. All measurements are given in millimetres (Table 1). The taxonomy follows Mlíkovský (2002) and Dickinson \& Remsen (2013). The osteological terminology is after Baumel \& Witmer (1993) and Livezey \& Zusi (2006).

Abbreviations: Anatomical: dex. - dextra; m. - musculus; prox. - proximalis; sin - sinistra; Institutional: NHM - Natural History Museum, formerly British Museum (Natural History), Tring; NMNHS - National Museum of Natural History (Bulgarian Academy of Sciences), Sofia.

\section{Systematic part}

Order GALLIFORMES (Temminck, 1820)

Family Phasianidae Horsfield, 1821

Subfamily Phasianinae Horsfield, 1821

Genus Phasianus Linnaeus, 1758

Phasianus bulgaricus sp. $n$.

Holotype: ulna prox. sin. NMNHS 15143 (Fig. 1), collections of the Vertebrate Animals Department of the
National Museum of Natural History, Sofia, Bulgarian Academy of Sciences. Collected in 2006 by the joint Bulgarian-French team, during the palaeontological field excavations, organised by the NMNHS.

Etymology: The name bulgaricus is given after the name of Bulgaria, the country where the specimen originates from.

Measurements: Table 1; Fig. 2.

Differential diagnosis: A medium-sized fossil species in the genus Phasianus, differing from the recent Phasianus colchicus by: (1) the wider depressio $\mathrm{m}$. brachialis; (2) the more approached medial edge of depressio $\mathrm{m}$. brachialis to the medial linea intermuscularis on the medial side of the bone; (3) wider impressio m. scapulotricipitis; (4) the blunt instead sharp, ending of depressio $\mathrm{m}$. brachialis at its proximal end; (5) more straight, instead bent lateral edge of the profile of the bone in dorsal view; (6) blunt instead sharp, ending of depressio $\mathrm{m}$. brachialis at its proximal end.

Preservation: The holotype represents a proximal bone fragment, which is almost $2 / 3$ of the total length of the bone (Fig. 1).

Locality: Vicinity of Gorna Sushitsa Village (Fig. 3), SE of town of Sandanski (Blagoevgrad Region, SW Bulgaria; Fig. 4); $41^{\circ} 555^{\prime} \mathrm{N}, 23^{\circ} 384^{\prime} \mathrm{E}$ (Spassov et al., 2019). UTM grid: FM73.

Chronology: MN11-12 zone, Middle Turolian (Spassov et al., 2019).

Description: The specimen is of good preservation. The distal third is missing and the total length of the bone fragment is $47.1 \mathrm{~mm}$. All morphological details of an ulna bone are excellently preserved, incl. lineae intermusculares, foramina nutritia, specific edges, papilae remigiales caudales, etc.

\section{Comparisons}

The specimen shows all the features of mediumsized gallinaceous birds - medium or even short ulna, well-developed (wide and relatively short) impressio brachialis and shallow relief on the facies articularis proximalis. Its morphological characteristic suggest the find belongs to Phasianidae (i.e. Phasianinae), see below. Both osteometrically and osteomorphologically the examined specimen approaches to genus Phasianus. Relatively blunt olecranon, crescent-shaped bent diaphysis, well-developed sharp proximal edge of depressio brachialis and the thicker proximal half 

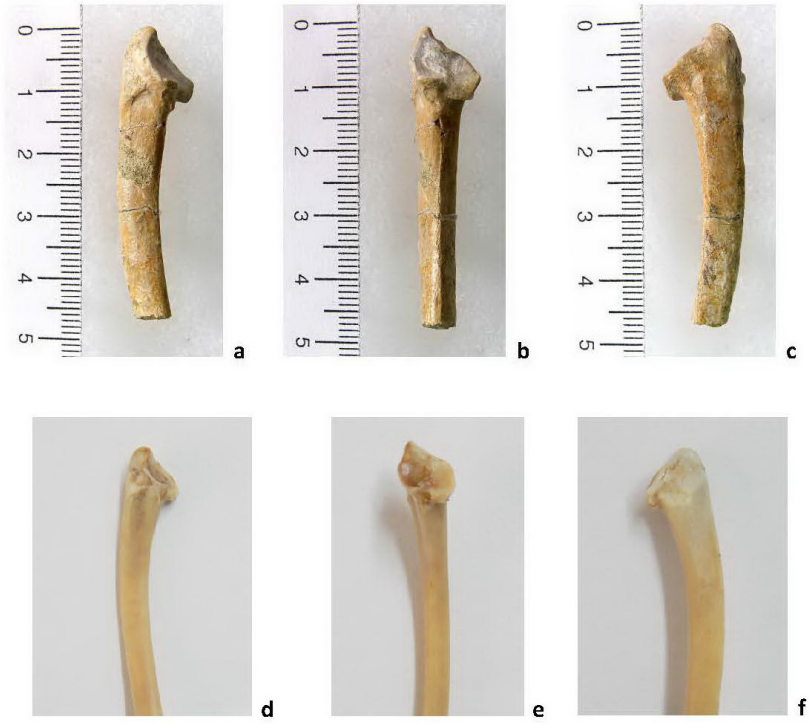

Fig. 1. Phasianus bulgaricus sp. n. - ulna sin. prox. NMNHS 15143 (holotype) Gorna Sushitsa Village (Blagoevgrad Region): ventral view (a), medial view (b), dorsal view (c). Photographs: Assen Ignatov; Phasianus colchicus sp. n. - ulna sin. prox. NMNHS 60/2016 Brestnitsa (Lovech Region, NC Bulgaria): ventral view (d), medial view (e), dorsal view (f). Photographs: Zlatozar Boev.

of the bone suggest a pheasant of Phasianus. In addition, the specimen NMNHS 15143 was compared with 38 phasianid species ( 23 recent and 15 fossil) to confirm it belongs to Phasianidae and to identify its genus.

- Comparison with recent phasianids

- Tetrao urogallus Linnaeus, 1758: smaller; deeper and well-developed impressio $\mathrm{m}$. scapulotricipitis on dorso-lateral side of the bone; shallower depressio $\mathrm{m}$. brachialis.

- Tetrao tetrix Linnaeus, 1758: similar by general morphology and size; much deeper and well-developed impressio $\mathrm{m}$. scapulotricipitis on dorsolateral side of the bone. In medial view pr. olecrani more massive, blunt and directed dorsally instead longitudinally. Depressio m. brachialis wider.

- Gallus lafayettii Lesson, 1831: larger; shallower cotyla ventralis.

- Gallus sonneratii Temminck, 1813: relatively shorter cotyla dorsalis (measurement "b"); wider depressio $\mathrm{m}$. brachialis.

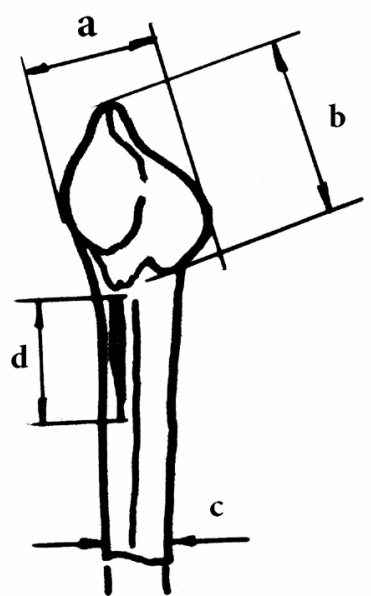

Fig. 2. Measurements of proximal ulna in large Phasianids, Drawing: Vera Htistova.

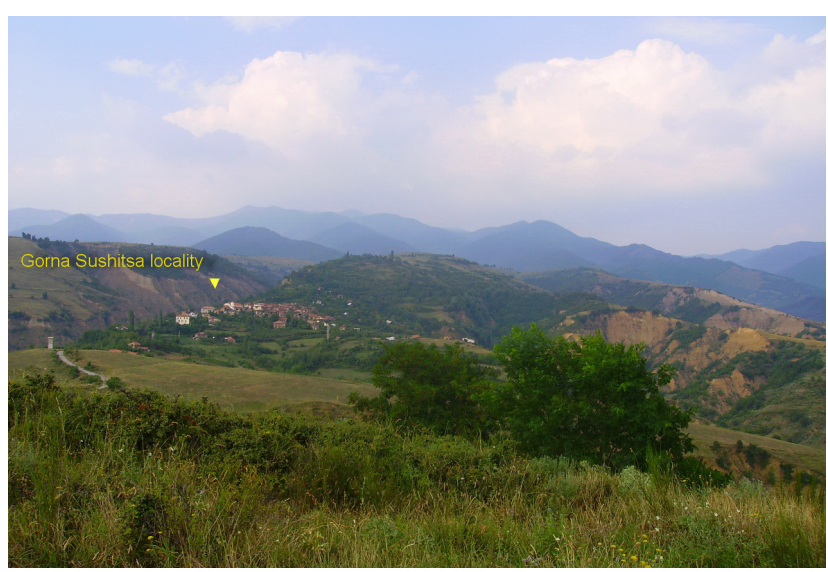

Fig. 3. Gorna Sushitsa locality and the present landscape in the surroundings of the Gorna Sushitsa Village. Photograph: Nikolay Spassov.

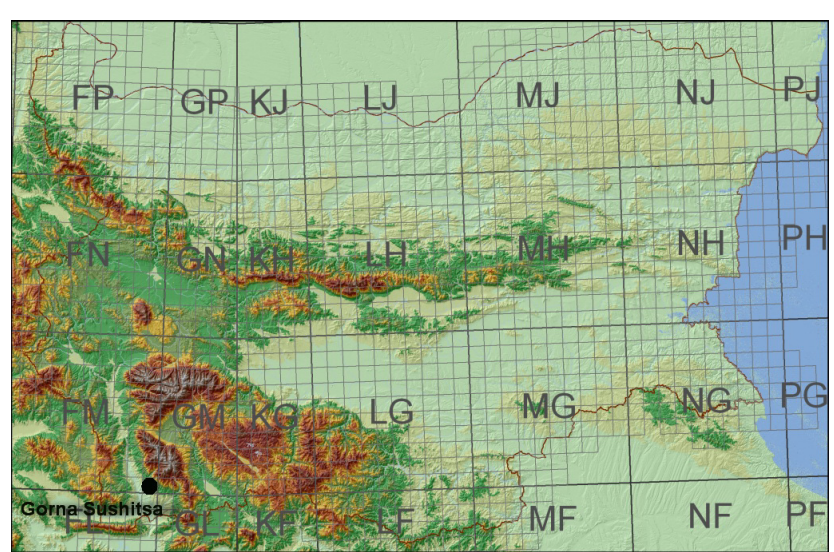

Fig. 4. Location of the Gorna Sushitsa locality. 
Table 1. Comparison of the measurements of the ulna prox. of fossil and recent Phasianidae (ref. to Fig. 2)

\begin{tabular}{|c|c|c|c|c|c|}
\hline Species & $\mathrm{a}$ & $\mathrm{b}$ & $\mathrm{c}$ & d & e \\
\hline \multicolumn{6}{|l|}{ Fossil - Gorna Sushitsa } \\
\hline Phasianus bulgaricus sp. n. NMNHS 15143 & 10.1 & 14.1 & 5.3 & ca. 16.0 & 4.4 \\
\hline \multicolumn{6}{|l|}{ Recent } \\
\hline Phasianus colchicus NHM 1979.10.1 & 9.8 & 13.8 & 5.0 & 11.9 & 4.9 \\
\hline Phasianus colchicus NHM 1985.9.1 & 8.3 & 12.4 & 3.9 & 10.8 & 4.3 \\
\hline Phasianus colchicus NHM 1985.42.1 & 7.8 & 12.0 & 3.9 & 8.2 & 3.0 \\
\hline Gallus lafayettei NHM 1985.42.1 & 6.7 & 10.0 & 3.5 & 8.0 & 2.1 \\
\hline Gallus sonneratii NHM 1985.42.2 & 8.2 & 12.8 & 4.6 & 10.0 & 4.0 \\
\hline Gallus sonneratii NHM 1975.105.13 & 8.9 & 13.0 & 4.5 & 10.0 & 3.7 \\
\hline Gallus gallus NHM 1850.8.15.21 [wild; Timor] & 8.0 & 12.0 & 3.9 & 11.3 & 3.8 \\
\hline Tragopan satyra NHM.12.3.5 & 87 & 13.2 & 4.2 & 12.0 & 3.1 \\
\hline Tragopan satyra NHM.18.67.12.3.4 & 10.5 & 15.3 & 5.3 & 12.6 & 3.4 \\
\hline Ithaginis cruentus NHM 1952.2.101 & 8.3 & ca. 12.8 & 4.3 & 11.2 & 3.3 \\
\hline Tragopan temminckii NHM 1999.11.2 & 7.7 & 11.8 & 4.0 & 10.8 & 3.2 \\
\hline Tragopan temminckii NHM 1976. 1.1 & 9.4 & 13.3 & 4.5 & 10.5 & 4.3 \\
\hline Tragopan caboti NHM 1976. 1.1 & 7.2 & 11.2 & 3.5 & 9.7 & 3.0 \\
\hline Lophophorus impejanus NHM 1977.19.1 & 10.9 & 16.8 & 5.4 & 13.2 & 4.4 \\
\hline Lophura leucomelanos NHM 1865.10.9.19 & 8.5 & 12.3 & 4.1 & 8.7 & 2.5 \\
\hline Crossptilon auritum NHM 1868.9.12.23 & 9.7 & 14.2 & 5.4 & 12.8 & 4.0 \\
\hline Lophura nycthemera NHM 1984. 75.1 & 8.8 & 12.3 & 4.9 & 10.8 & 3.5 \\
\hline Lophura ignita rufa NHM 1869.10.19.18 & 9.9 & 14.4 & 5.2 & 16.3 & 4.7 \\
\hline Lophura swinhoii NHM 1966.55.36 & 8.5 & 12.4 & 4.6 & 12.2 & 3.6 \\
\hline Lophura erythropthalmus NHM 1865.5.10.13 & 8.6 & 13.0 & 4.9 & 12.0 & 2.8 \\
\hline Chrysolophus pictus NHM 1850.11.13.16 & 5.7 & 8.4 & 3.0 & 6.0 & 2.3 \\
\hline Chrysolophus amherstiae NHM 1980.2.1 & 7.4 & 10.8 & 4.2 & ca. 9.8 & 2.2 \\
\hline Syrmaticus reevesi NHM 1867.5.22.1 & 8.6 & 11.8 & 4.9 & 10.7 & 3.4 \\
\hline Syrmaticus soemmerringi NHM 1952.2.130 & 8.7 & 12.4 & 4.1 & 10.5 & 3.9 \\
\hline Syrmaticus soemmerringi NHM 1860.8.25.7 & 8.4 & 12.8 & 4.0 & 9.8 & 3.5 \\
\hline Polyplectron chalcurum NHM 1848.10.31.9 & 6.1 & 7.6 & 3.3 & 7.8 & 1.7 \\
\hline Polyplectron emphanum NHM 1848.10.31.9 & 6.4 & 9.4 & 3.4 & 8.9 & 2.4 \\
\hline Polyplectron malacense NHM 1848.10.31.9 & 6.0 & 9.3 & 3.0 & 8.0 & ca. 1.8 \\
\hline Rheinardia ocellata NHM 1926.9.8.1169 & 10.8 & 13.9 & 4.4 & 13.3 & 3.9 \\
\hline Afropavo congensis NHM 1989.19.16 & 11.0 & 14.2 & 4.6 & 13.4 & 5.0 \\
\hline Afropavo congensis NHM 1977.20.1 & 10.3 & 5.2 & 5.5 & 4.2 & 4.6 \\
\hline Tetrao tetrix NHM 1952.2.19 & 10.0 & 14.4 & 5.2 & 14.7 & 3.9 \\
\hline Tetrao tetrix NHM 1952.2.21 & 8.2 & 12.2 & 4.2 & 13.3 & 2.7 \\
\hline Tetrao tetrix NHM 1930.3.24.18 & 9.5 & 13.7 & 4.8 & 13.3 & 3.6 \\
\hline Tetrao tetrix NHM 1952.2.20 & 8.8 & 13.5 & 4.5 & 12.3 & 3.1 \\
\hline Tetrao tetrix NHM 1909- 10.14.1 & 9.7 & 14.0 & 4.9 & 14.0 & 3.3 \\
\hline Tetrao tetrix NHM 1905.10.20.1 & 8.5 & 12.7 & 4.4 & 12.5 & 3.0 \\
\hline Tetrao tetrix NHM 1909.10.14.2 & 8.5 & 12.3 & 4.2 & 12.2 & 2.8 \\
\hline Tetrao tetrix NHM 1984.54.1 & 8.9 & 13.5 & 4.6 & 11.7 & 3.2 \\
\hline Tetrao urogallus NHM 1851.11.10.48 & 16.1 & 23.4 & 7.9 & 22.6 & 5.5 \\
\hline Tetrao urogallus NHM 1927.12.27.154 & 16.7 & 22.7 & 7.6 & 23.1 & 5.1 \\
\hline
\end{tabular}

- Gallus gallus bankiva Temminck, 1813 [wild; Timor]: larger; much less developed papilae remigiales caudales; wider depressio $\mathrm{m}$. brachialis.
- Tragopan satyra (Linnaeus, 1758): deeper and well-developed impressio m. scapulotricipitis; wider depressio m. brachialis; blunt instead sharp, 
ending of depressio m. brachialis at its proximal end.

- Ithaginis cruentus (Hardwicke, 1821): much less developed papilae remigiales caudales; wider depressio $\mathrm{m}$. brachialis; relatively thicker disaphysys in the proximal end; deeper impressio $\mathrm{m}$. scapulotricipitis.

- Tragopan temminckii (J.E. Gray, 1831): wider and shallower depressio $\mathrm{m}$. brachialis; rounder, instead angular dorsal edge of cotyla dorsalis.

- Tragopan caboti (Gould, 1857): larger; outlining edge of the depressio $\mathrm{m}$. brachialis in proximal end rounder, instead of sharpened.

- Lophophorus impejanus (Latham, 1790): deeper, elongated in shape, instead of short and triangular impressio m. scapulotricipitis; shallower depressio $\mathrm{m}$. brachialis in proximal end.

- Lophura leucomelanos (Latham, 1790): shallower depressio $\mathrm{m}$. brachialis in proximal end; deeper impressio m. scapulotricipitis.

- Crossptilon auritum (Pallas, 1811): less developed papilae remigiales caudales; wider depressio m. brachialis; thicker olecranon.

- Lophura nycthemera (Linnaeus, 1758): shallower medial edge of depressio m. brachialis; more straight diaphysys.

- Lophura ignita rufa (Raffles, 1822): deeper impressio m. scapulotricipitis; shallower cotyla ventralis.

- Lophura swinhoii (Gould, 1863): wider and shallower depressio $\mathrm{m}$. brachialis; edge of proximal end of depressio $\mathrm{m}$. brachialis rounder.

- Lophura erythrophthalma (Raffles, 1822): larger cotyla ventralis; deeper impressio m. scapulotricipitis.

- Syrmaticus reevesi (J. E. Gray, 1829) and Chrysolophus pictus (Linnaeus, 1758): larger; more robust; deeper impressio m. scapulotricipitis.

- Syrmaticus soemmerringi (Temminck, 1830): tip of olecranon directed more dorsally; deeper impressio m. scapulotricipitis.

- Chrysolophus amherstiae (Leadbeater, 1829): deeper and straight, instead of curved impressio m. scapulotricipitis.

- Polyplectron chalcurum Lesson, 1831, P. napoleonis Lesson, 1831 (labelled as $P$. emphanum), P. malacense (Scopoli, 1786): larger; relatively wider and shallower depressio $\mathrm{m}$. brachialis; tip of olecranon directed more dorsally.

- Rheinardia ocellata (Elliot, 1871): tip of olecra- non directed more dorsally; deeper impressio $\mathrm{m}$. scapulotricipitis; shape of the edge of depressio $\mathrm{m}$. brachialis more round at the proximal end.

- Afropavo congensis Chapin, 1936: cotyla dorsalis round, instead of angular; olecranon sharper; edge of depressio $\mathrm{m}$. brachialis in prox. end more transversal; shallower depressio $\mathrm{m}$. brachialis.

- Ph. colchicus Linnaeus, 1758: extremely similar (see differential diagnosis).

\section{- Comparison with fossil phasianids}

Tetrao conjugens Janossy, 1974 and T. partium (Kretzoi, 1961) are known from the early Pliocene to Late Pleistocene, while T. macropus Janossy, 1976 and T. praeurogallus Janossy, 1969 are Late Pliocene to Middle Pleistocene species (Janossy, 196). Tetrao rhodopensis Boev, 1998 is with considerable chronostratigraphic differences: dated to the Early Pliocene (Ruscinian, MN zone 14; 5.4-3.4 Ma) and lacking of homologous skeletal elements. The preserved distal humerus (which is part of the humeroulnar joint) of T. rhodopensis suggests much bigger proximal ulna and, thus, can be excluded from our comparison. Miogallus altus (Milne-Edwards, 1869) is another species with considerable chronostratigraphic differences: MN 3-8, and lacking of homologous skeletal elements (Mlikovsky, 2002; Sanchez-Marco, 2006). All species (recent and fossil) of Pavo Linnaeus, 1758 and Afropavo Chapin, 1936 are considerably larger, while these of genera Alectoris Kaup, 1829, Francolinus Stephens, 1819, Perdix Linnaeus, 1758, Arborophila Hodgson, 1837, Ammoperdix Gould, 1851, and Coturnix Bonnaterre, 1791 are much smaller than specimen NMNHS 15143. In the same way, all fossil taxa of the genera Paraortyx Gaillard, 1908, Palaeocryptonyx Depéret 1892, Bantamyx Kurochkin, 1982 and Pirortyx Brodkorb, 1964 are significantly smaller than the compared specimen is. Lophogallus naranbulakensis Zelenkov \& Kurochkin, 2010 is known with its humerus and femur from the Middle Miocene of Mongolia (Zelenkov \& Kurochkin, 2010), while Syrmaticus kozlovae Kurochkin, 1985 is known with its humerus and coracoid from the Middle Pliocene of Mongolia (Kurochkin, 1985). Thus, both are incomparable. The Miocene Linquornis gigantis Yeh, 1980 from China was a large pheasant, similar in size to Pavo (Zelenkov \& Kurochkin, 2010). Phasianus sp.: acording Mlikovsky (2002), the only Neogene re- 
cord of g. Phasianus in Europe came from the Early Pleistocene (formerly Late Pliocene; MN 17) locality of Varshets (NW Bulgaria). Boev (2002) listed a find of Phasianus sp. This specimen (NMNHS 256) represents a distal half of coracoid dex. Its age is Middle Villafranchian (MN 17) and could not be compared.

\section{Discussion}

The above-presented comparison shows that the NMNHS 15143 find could not be referred to any of the recent and fossil species belonging to the genus. The Pleistocene Palaearctic pheasants are of considerable chronostratigraphic differences. The Neogene Palaearctic record of true pheasants consists of finds of only "Phasianus sp.". Thus the Middle Turolian specimen of Gorna Sushitsa should be distinguished under a separate name as a new species. Phasianus bulgaricus sp. n. is the oldest known true pheasant in Europe.

The dominating semi-open-land grass/forested savannah habitat in the region, dating back to ca. 7.36 Mya, indicates the more open-habitat preferences of Ph. bulgaricus sp. $\mathrm{n}$. This completely agrees with the habitats of the large mammals fauna (Spassov et al., 2019).

\section{Acknowledgments}

The author is very grateful to Dr Robert Prys-Jones (NHM) for providing excellent working conditions in NHM, which facilitated much of this study. The Short-term Visits Program of the Royal Society (London, 2002) and the "Synthesis" Program (2007) of the European Council, and the NMNHS have supported the study.

Thanks also to Prof. Nikolai Spassov, who gave me the opportunity to study the fossil and provided me literature and to MSc Assen Ignatov for the photographs.

\section{References}

Baumel J.J., Witmer L.M. 1993 Osteologia. In: Baumel J., King, A., Breazile, J., Evans, H., Vanden Berge J. (eds). Handbook of avian anatomy: Nomina Anatomica Avium. Pub. Nutall Orn. Cl. 23. Cambridge, Massachusetts, 45-132.
Boev Z. 2002 Neogene avifauna of Bulgaria. In: Zhou Z., Zhang F. (eds). Proceedings of the 5th Symposium of the Society of Avian Palaeontology and Evolution, Beijing, 01-04.06.2000. Science Press, Beijing, 29-40.

Boev Z. (In prep.) Late Pleistocene birds from Thanh Hoa Province (Northern Vietnam). Historia naturalis bulgarica.

Böhme M., Van Baak Ch., Prieto J., Winklhofer M., Spassov N. 2018 Late Miocene stratigraphy, palaeoclimate and evolution of the Sandanski Basin (Bulgaria) and the chronology of the Pikermian faunal changes. Global and Planetary Change 170: 1-19.

Dickinson E.C., Remsen Jr. J.V. (eds) 2013 The Howard \& Moore Complete Checklist of the Birds of the World. $4^{\text {th }}$ Edition, Vol. 1, Aves Press, Eastboume, UK, $461 \mathrm{pp}$.

Janossy D. 1976 Plio-Pleistocene bird remains from the Carpathian basin. I. Galliformes. 1. Tetraonidae. Aquila 72: 13-36.

Kurochkin E.N. 1985 Birds of the Central Asia in Pliocene. The joint Soviet-Mongolian Paleontological Expedition. Transactions, 26. 120 pp.

Livezey B.C., Zusi R.L. 2006 Higher-order phylogeny of modern birds (Theropoda, Aves: Neornithes) based on comparative anatomy: I. Methods and Characters. Bulletin of Carnegie Museum of Natural History 37: 1-544.

Mein P. 1990 Updating of MN zones. In: Lindsay E.H., Fahlbusch V., Mein P. (eds): European Neogene mammal chronology. New York. Plenum Press, 73-90.

Mlíkovský J. 2002 Cenozoic Birds of the World. Part 1: Europe. Praha: Ninox Press., 406 pp.

Olson S. 1985 The fossil record of birds. In: King, J.R., Parker D.C. (eds). Avian Biology, Vol. VIII, Academic Press, New York, 79-252.

Sanchez-Marco A. 2006 Miophasianus and Palaeoperdix (Galliformes, Aves) from three Miocene localities of Spain. Estudios Geológicos 62 (1): 249-256.

Spassov N., Geraads D., Hristova L., Markov G. 2019 The late Miocene mammal fauna from Gorna Sushitsa, southwestern Bulgaria and the early/middle Turolian transition. Neues Jahrbuch für Geologie und Paläontologie Abhandlungen 291/3: 317-350.

Spassov N., Tzankov T., Geraads D. 2006 Late Neogene stratigraphy, biochronology, faunal diversity 
and environments of South-West Bulgaria (Struma River Valley). Geodiversitas 28 (3): 477-498.

Tyrberg T. 1998 Pleistocene birds of the Palearctic: a catalogue. Publications of the Nuttall Ornithological Club, Cambridge, Massatchusetts, 27. 720 pp.

Tyrberg T. 2008 Internet supplement to: Tyrberg, T. 1998 Pleistocene Birds of the Palearctic: A Catalogue. Publ. of the Nuttall Ornithol. Club, No 27.
Cambridge, Massachusetts. 1-720. Updated 24 February 2008: http://web.telia.com/ u11502098/ pleistocene.pdf

Zelenkov N.V., Kurochkin E.N. 2010 Neogene Phasianids (Aves: Phasianidae) of Central Asia: 3. Genera Lophogallus gen. nov. and Syrmaticus. Paleontological Journal 44 (3): 328-336. 